\section{Prestere på topp}

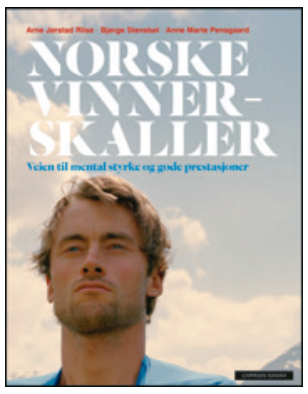

Arne Jørstad Riise, Bjørge Stensbøl,

Anne Marte Pensgaard

Norske vinnerskaller

Veien til mental styrke og gode prestasjoner 572 s, ill. Oslo: Cappelen Damm, 2013.

Pris NOK 399

ISBN 978-82-02-42187-8

Dette er en bok om de viktigste psykologiske teoriene og ferdighetene for å prestere godt. Selvtillit og tro på seg selv er viktig for å nå målet om å bedre prestasjonene våre. Boken er egnet for alle som arbeider med å styrke psykiske faktorer og bedre mentale ferdigheter under prestasjonspress. Den kan anbefales til alle som driver pedagogisk og personlighetsmessig utviklingsarbeid innenfor idrett, musikk, helsearbeid og i skolen.

Forfatterne presenterer teorier på en oversiktlig og god måte. De binder dem sammen med veldokumentert, generell psykologisk teori. Hovedpoengene er klare og enkle, uten å bli overfladiske. De går også tilstrekkelig i dybden samtidig som de opprettholder leserens interesse for det som kommer senere. Et eksempel på dette er deres beskrivelse av hvordan de fire basisteknikkene i mental trening, målsetting, visualisering, avspenning og indre dialog, knyttes til Ryan og Decis' godt empirisk dokumenterte selvbestemmelsesteori.

På en utmerket måte klargjør og konkretiserer forfatterne viktig trening for gode vaner og holdninger i prestasjonsarbeidet. Særlig vektlegger de betydningen av langsiktig arbeid, tålmodighet og relevant øving. Det er når denne automatikken er oppnådd og blitt en automatisk vane at individet fremstår med en trygghet og selvtillit som virkelig hjelper.

I teorikapitlet fremsetter de en teori som de kaller TATOOmodellen. Modellen inneholder de viktigste elementene vi må arbeide etter for å lykkes i å prestere på vårt beste. Denne generelle teoretiske bakgrunnen gjør de individuelle beskrivelsene av 30 av våre norske enere og verdensmestere spennende og belysende. I beskrivelsen ivaretar de betydningen av å være åpen for viktige individuelle variasjoner. De viser at grunnleggende evner hos den enkelte må oppdages, bekreftes og brukes i arbeidet. Videreutvikling av disse egenskapene blir vesentlig for å lykkes. Nettopp dette gjør boken mer spennende å lese.

De avslutter med en oppsummering av det de kaller sentrale ferdigheter hos toppidrettsutøvere, og lister opp i alt 26 slike sentrale ferdigheter. Dette er viktige holdninger og vaner som vi alle kan ha nytte av å lære og bruke i eget utviklingsarbeid.

Generelt synes jeg dette er en meget god og leseverdig bok. Den er nyttig for alle som er interessert $i$ å hjelpe andre og seg selv frem mot bedre prestasjoner. Boken har høy kvalitet og er egnet som oppslagsverk på området.

Bjørn Wormnes

Førsteamanuensis, Psykologisk fakultet

Universitetet i Bergen

\section{iPhone - ditt neste pulsoksimeter?}

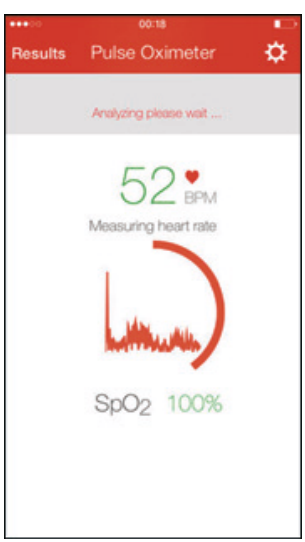

\author{
digiDoc Technologies AS \\ Pulse 0ximeter
}

versjon 1.3.3

App til iPhone og iPod touch. 2,2 MB.

Språk: Engelsk. Pris: NOK 14

Pulsmåling med smarttelefon har vært mulig lenge og baserer seg på en patent fra 1970-årene. Kamera i smarttelefonen måler endringer i brytningen av kameralyset når en finger dekker kamera og lys samtidig. Utviklerne av appen Pulse Oximeter har benyttet det samme prinsippet for samtidig å måle perifer oksygenmetning $\left(\mathrm{SpO}_{2}\right)$ i blodet. Appen lanseres under kategorien Helse og Trening i App Store, men utviklerne gjør det klart at den ikke er godkjent for medisinsk bruk.

Appen har en enkel grafisk utforming som er oversiktlig og intuitiv. Kamera må kalibrere seg i et par sekunder før man kan legge fingeren over fotolyset og kamera. Selve målingen tar noen få sekunder. Resultatene av målingene lagres i en liste med dato og tid. Appen inneholder en enkel, men nyttig illustrert instruksjon for hvordan man måler puls og $\mathrm{SpO}_{2}$. Det er også mulig å ta kontakt med utviklerne for å gi tilbakemelding på appen, og det er en egen «ofte spurte spørsmål»-seksjon med nyttige tips.

Jeg har testet appen en del på meg selv, og sammenliknet resultatene med målinger på ordinært pulsoksimeter på jobb. Inntil siste oppdatering av appen var målingene svært avhengige av riktig plassering av fingeren over kamera og lys. Med versjon 1.3.3 er dette mye bedre, selv om noen målinger fortsatt svikter hvis fingeren for eksempel dekker fotolyset litt for dårlig. Når man plasserer fingeren riktig, er resultatene forbausende riktige. Dette gjelder imidlertid for $\mathrm{SpO}_{2}$-verdier mellom $92 \%$ og $100 \%$ da jeg ikke har klart å påføre meg selv lavere oksygenmetning i forbindelse med testing av appen.

Appen har begrenset klinisk nytte slik den foreligger i dag, til det er målingene for upålitelige. Medisinskteknisk utstyr krever omfattende godkjenning, men Federal Drug Administration i USA har allerede begynt å godkjenne apper til medisinsk bruk, så det er ikke utenkelig at Pulse Oximeter eller andre tilsvarende apper med tiden kan bli godkjent. Hvis utviklerne klarer å finjustere algoritmen som ligger bak målingen ytterligere, slik at den blir mer pålitelig og man kan utføre klinisk testing, kan dette være en klinisk nyttig app for enkelte pasientgrupper. Det gjelder for eksempel pasienter med kols, eller for fastlegen eller legevaktslegen på sykehusbesøk. Inntil godkjenning for medisinsk bruk foreligger, er Pulse Oximeter likevel en interessant nyvinning som man som teknologiinteressert lege bør koste på seg. Om ikke annet for å støtte utviklerne i sitt videre arbeide med appen.

Stephen J.M. Sollid

Overlege, Luftambulanseavdelingen

Oslo universitetssykehus, Ullevål 